Article

\title{
Individual or Structural Inequality? Access and Barriers in Welfare Services for Women Who Sell Sex
}

\author{
Anette Brunovskis ${ }^{1, *}$ and May-Len Skilbrei ${ }^{2}$ \\ ${ }^{1}$ Fafo Institute for Labour and Social Research, 0608 Oslo, Norway; E-Mail: anette.brunovskis@fafo.no \\ ${ }^{2}$ Department of Criminology and Sociology of Law, University of Oslo, 0130 Oslo, Norway; E-Mail: m.I.skilbrei@jus.uio.no \\ * Corresponding author
}

Submitted: 6 April 2018 | Accepted: 5 September 2018 | Published: 28 September 2018

\begin{abstract}
It is often taken for granted that women who sell sex are vulnerable, that welfare services can and should alleviate this vulnerability, and as such, being defined as 'vulnerable' can be beneficial and associated with special rights that would otherwise be inaccessible. At the same time, ongoing debates have demonstrated that establishing individuals and groups as vulnerable tends to mask structural factors in inequality and has negative consequences, among them an idea that the path to 'non-vulnerability' lies in changing the 'afflicted' individuals or groups, not in structures or in addressing unequal access to resources. In this article, we take this as a starting point and discuss challenges for the welfare state in meeting the varied and often complex needs of sex sellers. Based on qualitative research with service providers in specialised social and health services in Norway, we examine access and barriers to services among female sex sellers as well as how vulnerability is understood and shapes what services are available. An important feature of modern prostitution in Norway, as in the rest of Western Europe, is that sex sellers are predominantly migrants with varying migration status and corresponding rights to services. This has influenced the options available to address prostitution as a phenomenon within the welfare state and measures that have previously been helpful for domestic women in prostitution are not easily replicated for the current target population. A starting point in a theoretical understanding that considers vulnerability to be a human predicament (rather than the exception to the rule or a deficit in individuals or groups) allows for a discussion that highlights the centrality of structural conditions rather than a need for change in the individual. In order to understand the limitations of the welfare state in addressing modern prostitution as such, it is highly relevant to look at the structural origin of vulnerabilities that may look individual.
\end{abstract}

\section{Keywords}

human trafficking; migration; prostitution; service access; vulnerability; welfare

\section{Issue}

This article is part of the issue "Vulnerable and Disadvantaged Groups: On the Margins of the Welfare State?", edited by Inger Lise Skog Hansen and Tone Fløtten (Fafo Institute for Labour and Social Research, Norway).

(C) 2018 by the authors; licensee Cogitatio (Lisbon, Portugal). This article is licensed under a Creative Commons Attribution 4.0 International License (CC BY).

\section{Introduction}

Women who sell sexual services are generally considered to be an especially vulnerable group (Brown \& Sanders, 2017), and are, in many countries, the target of specialised welfare services. In many contexts, prostitution is considered to be a social or criminal problem to be limited, if not eradicated. In several European countries this has entailed an increasing reliance on criminal justice approaches to combat prostitution, and Norway, and even more so its neighbouring Sweden, is known for its abolitionist approach to prostitution and unilateral criminalisation of the purchase of sex (Skilbrei \& Holmström, 2013). The background for this approach is an understanding of prostitution as inherently harmful, both because it is populated with vulnerable persons and be- 
cause it exacerbates or creates vulnerabilities. In the last couple of decades, the emphasis on vulnerability in prostitution has also been reinforced under the influence of the international human trafficking policy framework, which is currently an often-applied lens when discussing and responding to prostitution. What is often less explicitly discussed is in what sense(s) female sex sellers are vulnerable and how vulnerability is understood and expressed in the shaping of services that particularly target this group.

In this article, we examine access and barriers to services among female sex sellers, as well as how the accessibility of certain services, but not others, reflects a particular understanding of vulnerability in services targeting sex sellers. We also discuss whether, and to what extent, current services address needs as observed by social workers and expressed by sex sellers. Current challenges for welfare provision in this group are closely intertwined with developments starting before the turn of the millennium when prostitution markets in most of Western Europe became decidedly transnational and now involve a very diverse population (Wagenaar, 2017). The fact that the population has become more diverse is particularly important as there now are considerable differences in the legal rights of the individuals involved, meaning that they have very different access to resources, both in welfare service terms and in access to resources, more broadly. This means that the forms that vulnerability among sex sellers may take are neither obvious nor uniform. Nonetheless, policies and services are often universal and sometimes rest on implicit, and at other times explicit, understandings of vulnerability among sex sellers. As we will argue in this article, an underlying premise in prostitution policy is that vulnerability is understood as an individual quality, whereas structural factors that predicate the distribution of resources and rights are not addressed.

The issue of terminology is central in scholarship on prostitution. The terms applied have different connotations and histories, and while some are interpreted to be demeaning, others are interpreted to be political (for debates on terminology see, Koken, 2010; Skilbrei, 2017). In this article, we refer to 'prostitution' as the field where money is transacted for sexual acts and services. The reason for not calling the activity 'sex work' is that that term encompasses a broad range of acts, including striptease and webcam, while the service provision we study here is offered only to people who engage in a direct exchange of sex for money. We refer to the people who operate in prostitution as sex-sellers, women who sell sex and similar services.

Our discussion begins by assessing the challenges the welfare state faces in meeting the needs of women who sell sex in Norway. We present and discuss some examples of practices and identified challenges in offering welfare to migrant women who sell sex that, while not exhaustive, we nonetheless find illustrative of broader concerns and developments. The population of sex sellers is diverse and its composition can change quite rapidly. This means that it is challenging to offer services that fit with the needs of the group. A characteristic in the rollout of welfare services to this group is that municipal and NGO services operate in tandem, and sometimes overlap each other. This produces a particular dynamic between ideology, official policies, and practice, something which is a backdrop to the analysis.

\subsection{Method}

We have, in the past two decades, conducted a series of research projects where we have interviewed service providers and women who sell sex in Norway about social and health needs (Brunovskis, 2012, 2013; Brunovskis \& Skilbrei, 2016; Brunovskis, Tveit, \& Skilbrei, 2010; Brunovskis \& Tyldum, 2004; Jahnsen \& Skilbrei, 2018; Tveit \& Skilbrei, 2008). Findings from these studies form an important part of the basis for our discussion in this article, and we revisit the material in the perspective of how 'vulnerability' plays out and is understood in service provision. Our analysis is further supplemented with interviews conducted as part of the Health Services and Health Needs in Prostitution project, in which we explicitly examined whether services offered match services needed, and what ideologies and concerns underpin the formulation and balancing of services. In this project, we conducted qualitative interviews with social workers $(n=35)$, sex sellers $(n=22)$, and representatives of police and prosecution $(n=10)$. In this article, we draw on the interviews with service providers working in the prostitution field. In these, we were interested in looking at existing conceptions of vulnerability and in how these play out in the practice of those who are tasked with front-line service provision in the welfare state. The methodological approach and respondent recruitment were similar in all projects (see each study for a more detailed description of data, methodology and ethical considerations). Respondents who were included in the research in their professional capacity were approached directly for interviews by email and provided with written project information. Interviews were semistructured and unstructured in form and included questions on understandings of needs in the prostitution field, specific and daily practice, as well as institutional frameworks and regulations of welfare provision. Our material includes respondents from four of the biggest cities in Norway (Oslo, Bergen, Stavanger and Trondheim) and was conducted in accordance with ethical procedures as developed and implemented by the Norwegian National Research Ethics Committees and the Norwegian Centre for Research Data.

\section{Defining Vulnerability}

Vulnerability has become a central concern for policymakers, and an 'ethos of vulnerability' - the overarching idea that some groups are particularly vulnerable and 
that this demands service provision and policy-makingis often institutionalised in the form of special provisions and increased control (Brown, 2015; Brunila \& Rossi, 2017). While this is a response to the realisation that not all people are equally positioned vis à vis material and social resources, the centrality of vulnerability as a steering principle in social policy and how vulnerability has been operationalised and affects people's lives, has been critiqued. While being defined as vulnerable and retaining special rights and protections in that capacity may seem beneficial, this can also have negative consequences both on individual and group levels. This point can be exemplified with examples from our own previous research. When female migrants, per definition, are deemed vulnerable and particular migration barriers are set up to protect them, this causes a need for women to use migration brokers instead of traveling independently, something which makes them vulnerable for exploitation (Andrijasevic, 2010; Demleiter, 2001). Martha Fineman draws attention to how we, by establishing groups and situations as 'vulnerable', treat vulnerability as an exception to the rule. She suggests that we instead think of vulnerability as a human predicament and investigate its expressions intersectionally. She has developed her vulnerability theory to counteract prevailing conceptions about the autonomous individual in liberal thought (Fineman, 2017).

Further, Fineman and others show how special protections for individuals may also produce more control of the same individuals, among other things, because of how vulnerability comes to be attached to femininity (Fineman, 2008; Singh, 2017). Treating vulnerability as a given dismantles the dichotomy between the vulnerable and the invulnerable, but also unsettles the relationship between vulnerability and other dichotomies (Singh, 2017), especially women/men, child/adult and Western/non-Western. This critique does not offer as a solution to do away with linking vulnerability and power but instead encourages scholars to investigate what this link actually is. Problematising how vulnerability is often defined and operationalised is also necessary out of concerns over what policies this encourages. If 'vulnerability' comes to look like a deficit in the individual or in particular groups, policies directed at 'fixing people' appear most relevant. If vulnerability is instead seen as universal and structural, different solutions come into view (Fineman, 2017, p. 3; see also FitzGerald, 2010). In this article, we will add to ongoing debates on vulnerability by exploring what the designation of someone as 'vulnerable' does in the particular context of service provision to women who sell sex. The study of intentions behind content and consequences of prostitution policies have, in the last ten years, become a much more important part of prostitution scholarship (see, e.g., Jahnsen \& Wagenaar, 2017; Showden \& Majic, 2014; Ward \& Wylie, 2017). Several scholars have pointed to how considering women involved in prostitution as vulnerable is something that has caused in- creased surveillance and other repressive interventions by police that affect them negatively (Blanchette $\&$ da Silva, 2014; de Pérez, 2016; Jahnsen \& Skilbrei, 2018). Very few of these contributions explicitly deal with social and health policies. Whether and how sex sellers are defined to be vulnerable also stems from political and ideological positions vis à vis prostitution, linking it to either an understanding of prostitution as inherently harmful or seeing harm in prostitution as situational or as a result of harmful repressive policies (for a presentation of these debates see, Weitzer, 2012). This means that welfare services, their contents, and foundations must be understood as expressions of particular positions and understandings of vulnerability that have significance beyond 'just' welfare provision.

\section{Principled Welfare Provisions and Pragmatic Deliverance}

The Norwegian welfare state is universal in its approach, but its main provisions are only entitlements for citizens and others that legally reside in the country, and some are also only provided to people based on membership in the National Insurance Scheme (Folketrygden) or labour market participation above a certain level (Hatland, 2013). While the public sector in Norway is large and its provision of services is extensive, civil society has an important role to play in delivering, developing, and pushing for welfare services (Loga, 2018). Specialised social work directed toward women who sell sex is a typical representative of this characteristic. It is both offered by municipality-run services and civil society actors, especially the Church City Mission, which has a long history in offering low threshold services to marginalised populations.

There are specialised services directed toward women who sell sex in four Norwegian cities. In three of these, there are both municipal-run and civil societyrun services. On the one hand, they often offer similar services, on the other, they aim to complement each other somewhat and they periodically organise meetings to ensure complementarity. Services are diverse in the sense that it depends on whether they do outreach, whether they have integrated health services, and how low the threshold is for accessing services. We will not describe and discuss the full scope of services here but rather look at how service providers describe services and how clients receive them. Here, it is sufficient to briefly convey their main functions.

Today, an important aspect of service provision is that prostitution-specific services, to some extent, function as intermediaries between female sex sellers and universal welfare services (when applicable). This entails assistance in filling out applications or in communication with relevant welfare state services, explaining procedures, and translating and/or explaining information. Social workers typically approach the opportunities available in the system quite pragmatically, and this goes for 
both public and private service providers. An important tool for the role as an intermediary is to ensure that initial meetings between social workers and sex sellers serve to map needs, rights, and opportunities. In addition, social work institutions/organisations also offer their own services which vary regarding ideological orientation and resources. While all social and health-promoting work towards women who sell sex is stated to be harm reductive, the various services strike a different balance between harm reduction and focusing on exiting from prostitution (Skilbrei \& Holmström, 2013). Similar to what is discussed in services to drug users as harm reduction versus recovery, these two ethos and methodologies are not necessarily combinable (Paylor, 2018).

\section{Provision of Welfare to Vulnerable Subjects}

As noted in the introduction, our goal is to investigate how services reflect certain understandings of vulnerabilities and needs and discuss challenges for the welfare state in meeting the varied and complex needs of female sex sellers. In this section, we first provide examples of, and discuss, different services, access, and barriers before we move on to what dominant understandings of vulnerability are currently reflected in service development and provision. We close this section with a discussion of whether, and to what extent, current services address needs as observed by social workers and expressed by sex sellers.

As described above, welfare services targeted at this particular group are explicitly aimed at harm reduction at an individual (and societal) level. Entry-level services tend to focus on (sexual) health and management of possible negative consequences of prostitution as such (which are understood to be harm-reductive measures). Diagnosing and treating sexually transmitted diseases (STDs) is prioritised and services readily offer help with this. In one city, NGO services had a standing agreement with an STD clinic in which a doctor would see the women the NGO services worked with, regardless of their health rights as determined by migration status. These check-ups were strictly limited to STDs, and other health needs would have to be covered through other health services. Sex sellers may have considerable health issues they need help with, however, if the health problem is not related to an STD, their legal status is often a considerable barrier. One social worker said:

Norway is a very rights-based society, so if you need to go further than just getting birth control pills or a chlamydia check-up, it's not easy. If you have psychological problems or other....HIV is fine, because then you have a right to treatment while you're here, but anything that is beyond the minimum.....And strictly speaking, in terms of [the STD clinic], I can't really claim that that is something they have a right to either.
STD health services are thus more quickly accessed, but also provided to women who, under other circumstances, would not access such services due to status as irregular migrants. This makes such health issues and services an exception to the rule-barriers to this particular form of health care have been addressed and, to a large extent, removed in practice, while at the same time, from an individual perspective, other health needs may be more pressing, more important to address and yet far less accessible. Sexual health and particularly STDs are thus seen as an important individual vulnerability. It should also be noted that its prioritisation also has a public health rationale beyond care for the individual patient, in limiting STDs in the general population, which is an approach to prostitution that has long historical traditions. The view that sex sellers constitute a public health danger is also evident from how STD checks are the main welfare service to men who buy sex in Norway (Sex og Samfunn, n.d.).

Access to other health services may be limited by legal rights, but also by the general legal approach to prostitution in Norway: while it is not illegal to sell sex in Norway, the criminalisation of clients and third parties-not least landlords who provide residence to persons who sell sex-also influences the situation of sex sellers and their relationships with services, as they are reportedly reluctant to give their addresses for fear of being evicted. Providing an address is normally required when seeking health services. One social worker exemplified this with a story of a woman who had been abused by a client and urgently needed medical attention but did not want to see a doctor because she did not want to give her address. The social worker then spoke with the emergency room in advance, explained the situation, and was told it was fine to come anyway. She took the woman to the doctor and waited outside. However, after a short time, the woman came back out, visibly upset and wanting to leave, and said she had been asked about her address. When she said she did not have one, she had reportedly been told she needed to go to the police and was also asked why she had not been to the police. This had scared her. In practice, then, while the social worker had to some extent been successful in lowering the barrier to accessing necessary health care for her client by personally intervening, the intersection with the legal regulation of prostitution in Norway (and the feared implication of divulging an address) had effectively put that barrier back up again. This example also reflects the fragility in access and barriers in services in terms of understanding the particular structural conditioning of vulnerability for sex sellers. While the act of a doctor encouraging a patient subjected to violence to seek out the police for recourse and protection might in most cases be logical, caring, and an attempt to reduce her vulnerability, the legal regulation of prostitution creates a particular brand of structural vulnerability that gives this a very different significance and meant that it was perceived as threatening. 
The intersection of rights as directly governed by migration legislation with consequences of prostitution policies, more broadly, is central in mediating vulnerability and the access or non-access to services. Lack of legal migration status will, under normal circumstances, also mean a lack of rights to services, but an important exception came into force at the turn of the millennium, with the introduction of the human trafficking policy framework. This signified an important change in how vulnerability in prostitution was dealt with and understood both in Norway and internationally and helping those perceived as forced by others to sell sex became an important political prioritisation. Part of this policy was also to reduce barriers to welfare access for this particular group, through special measures: being defined as a possible trafficking victim provides an inroad to Norwegian welfare services independently of other legal migration statuses, as identification as a victim of trafficking gives a low threshold right to a residence and work permit for six months. This is renewable for one year if the person cooperates with the police and their presence is necessary for an investigation of traffickers. It should be noted that while this status gives formal access to comprehensive services, this access is, in reality, complicated by a number of formal and informal factors (Brunovskis, 2016). Nevertheless, it is an important indicator of how vulnerability in transnational prostitution is currently understood and addressed.

While this represented a rather drastic change in the legal rights for persons who had been exploited in different ways, the human trafficking policy framework has been criticised for failing to recognise and precisely address the structural conditions and class, race, and gender inequalities that make exploitation possible, focussing instead on individual vulnerabilities and individual perpetrators of crime (see, e.g., Brunovskis \& Skilbrei, 2016; Kempadoo, 2005; Lee, 2007). This can be seen as mirrored in services to trafficking victims in Norway in that they focus on health needs and physical protection from retribution from traffickers, but only to a very limited extent address socio-economic vulnerability, which is, for many, their greatest need (Brunovskis et al., 2010). The introduction of the human trafficking framework meant that looking for specific vulnerability factors associated with human trafficking became part of services directed at women in prostitution. Social workers might try to elicit information about social relationships, debts, travel routes, living arrangements, etc, with the aim of identifying human trafficking, since this could open some avenues of welfare provision that are otherwise unavailable. However, social workers often found that these issues were seen as less relevant and not reflective of real needs by the women they worked with and that available measures were insufficient to make any substantial change in the women's lives:

Their financial situation has not been solved even if they've been given a six-month residence permit.
Their [pimp] may still be pressuring them [for money]. And the family at home will wonder why, after living in Europe for a year and a half, you haven't sent any money home.

This quote from a social worker also underlines an additional, important perspective on vulnerability that is generally missing in the welfare provision to migrant sex sellers, be they defined as trafficking victims or not; their social context and the often relational nature of their vulnerabilities. One of the main issues for many women has been the expectancy from family at home that they remit money. Failure to do so has been a considerable problem for trafficking victims returning to their home countries in their relationships with their families. There are also indications that some level of economic success mitigates the potential stigmatisation of women who have been involved in prostitution (Brunovskis \& Surtees, 2013; Plambech, 2014). However, at present, only one measure addresses education and employment opportunities for women who have been categorised as trafficking victims. Through a series of vocational courses, a few women are offered education in various aspects of the beauty industry and are also provided with a starter kit of equipment that provides the potential for them to start a small business. While long-term outcomes have not been evaluated, this education is invariably lauded by a wide range of actors involved in welfare provision in prostitution and held as an example of an actually useful approach.

Comparing this gap between needs and services with what appear to be previously successful approaches to addressing vulnerability in prostitution is illustrative of some of the main obstacles for the welfare state to address regarding prostitution today: for Norwegian women, a central vulnerability has historically been addiction. Initial welfare services were set up to meet their needs, and this group was, for a long time, the default target when services were developed and implemented. This group is very small today and, with the strengthening of drug rehabilitation and harm-reductive schemes, their needs are no longer generally unfulfilled or considered to be prostitution-related and therefore not on the agenda for the specialised prostitution services. This group is, thus, most often provided services through the universal welfare system and the main focus tends to be on treating the addiction itself and, as such, addressing the deeper vulnerability. This does seem to have been successful to a large extent. Following changes in the medication-assisted treatment (MAT) programme, Norwegian women with addictions more or less disappeared from street prostitution, an arena they had previously dominated. As noted by a social worker in a prostitution outreach programme:

[Norwegian women with addictions] are not really our target group. Many of them have a large team around them, and social services and many others who can 
contribute to health. I had contact with a Norwegian woman once and offered to take her to the [STD] clinic, but I think she found help elsewhere.

The considerable drop in the numbers of Norwegian women with addiction in prostitution also points to the success of welfare interventions that address actual needs. At the same time, it should be considered that developing services that catered to new groups with new vulnerabilities also served to marginalise Norwegian women from targeted welfare services (Tveit \& Skilbrei, 2008). Since the mid-2000s, migrants who sell sex, whether they are feared to be victims of trafficking or not, have been main targets in both debates and service development. Concerns over enhanced vulnerabilities among migrants meant that both policing and welfare resources were directed towards them, a development that, for Norwegian women who sell sex, has had both benefits and costs. Nonetheless, providing effective addiction treatment removed the need for money that was a driving factor in prostitution. Within the current approach to prostitution in Norway, there are no equivalent efforts to address actual needs among migrant sex sellers that might reduce their vulnerabilities or, in some cases, make prostitution redundant. A goal for Norwegian prostitution policy is to reduce the market, but the lack of services that could facilitate leaving prostitution means that this also becomes an individual responsibility-the economic rationale and necessity for many women selling sex in Norway today is not addressed.

\section{Discussion}

Norway and the other Scandinavian countries are considered the exception to the rule of increasingly approaching societal problems with punitive means (Smith \& Ugelvik, 2017). Instead of turning to criminal law, these countries typically develop welfare oriented measures that deal with the root causes of acts considered to be problematic. While this analysis of Scandinavian policy is debatable and has its exceptions, it is clear that these countries have a more comprehensive web of measures to deal with social problems than most other countries. Nevertheless, there are profound challenges for the welfare state in addressing prostitution in its modernday forms.

While prostitution is an issue considered to have national political and symbolic significance for society more broadly, its subjects, to a large extent, lead transnational lives. This is only, to a very limited extent, incorporated in prostitution policy pertaining to tools and options within the welfare state. When the overwhelming majority of female sex sellers are migrants, this influences the services available to sex sellers (depending on their formal migration status), the nature and time span of their contact with welfare providers, as well as the time span available for welfare provision. Given the premise that many who sell sexual services have complex needs, and given that prostitution as a phenomenon is unwanted in the Norwegian society, it must also be recognised that the tools and services available today are more limited than before. A perspective that examines vulnerabilities and welfare provision in a broader perspective brings this to light and also highlights the current limitations of the welfare state in addressing prostitution, both as a social phenomenon and for its individual actors.

The challenges for the welfare state in addressing prostitution are concurrent with an increased importance of criminal justice approaches and the policing of prostitution. Given the prominence on political agendas of how to best deal with prostitution and given that research consistently points to welfare and migrationrelated needs among sex sellers as key both to harm reduction and to the potential reduction of prostitution as such, the continued focus on criminal justice approaches is paradoxical. It is, however, consistent with developments in migration control that increasingly comes to merge with, and serves to support, criminal justice aims and institutions (Stumpf, 2006).

The limitations of the welfare state's ability to address prostitution have left the field open to criminal justice regulation and an ambiguous (if not contradictory) approach to sex sellers: they are considered to be vulnerable and worthy of help, but if they remain involved in prostitution the policing of prostitution will make their lives even worse, as it will it make it harder for them to earn money and find a place to live (Jahnsen \& Skilbrei, 2018). This is even more evident in the case of neighbouring Sweden, where social service providers report that they cannot offer harm-reductive measures, as aiding women who continue to sell sex is in breach of an abolitionist approach (Florin, 2012). In most cases, this approach particularly fails to recognise the importance of economic need as a driving force in prostitution. While not all prostitution is based in destitution or survival, the motivation of the women themselves to improve their lives, as well as their families' expectancies of, and reliance on, remittances can be a considerable upholding factor that could potentially be alleviated with access to alternative income. This is a solution that is both obvious, yet glaringly absent from political discussions on how to address modern-day prostitution.

While the dramatic change of prostitution that came with migration is an important factor in understanding vulnerability and the challenges for the welfare state, it is important not to assume that migration automatically leads to a heightened vulnerability among sex sellers. Migration and living transnational lives may both decrease and increase vulnerability in prostitution. The migration aspect of prostitution has very different implications in different groups: one pattern is to live 'two lives' (one of 'normalcy' and little/no marginalisation in their home country (Skilbrei, 2007). In these cases, it is precisely the transnational aspect of prostitution that protects against, e.g., stigma and social fallout. It may also allow a strategy for social mobility that would otherwise 
be inaccessible. On the other hand, another pattern is one of 'transnational marginalisation', including being marginalised also in their home country. The most prominent example of such circumstances in Norway is probably Roma women from Bulgaria and Romania (Kock, 2017). This is an under-studied group for a multitude of reasons (see, e.g., Siegel, 2015), but one might speculate that moving from place to place can, for some, contribute to heightened vulnerability-for instance, if they become less visible to social surroundings or services in their home country, services in destination country/countries may have limited responsibility and/or options for interventions, they may be less likely to seek (or get) help in a country where they lack citizenship (described in Shubin, 2010, in the case of Roma migrants in Scotland). What is important is to understand how migration and migration status intersect with vulnerability.

As we have demonstrated in this article, the relationship between access and barriers to services for female sex sellers is also not entirely straightforward. Generally, the provision of welfare and rights is allocated to members of a bounded community allowing access to others only under very specific circumstances (Barker, 2018; Boccagni, 2017; Mingot \& Mazzucato, 2018). While this creates a situation where migrant women who sell sex lack formal rights vis á vis universal welfare and health schemes, the fact that they sell sex also facilitates other routes to formal access and informal arrangements established on an understanding of them as particularly vulnerable. Nonetheless, while their 'vulnerability status' does facilitate some access that is not afforded other groups, it is far from comprehensive and, in many cases, not responsive to individual needs, but rather to needs that providers perhaps particularly associate with prostitution, namely STDs. Also, by not including them in universal health services and welfare schemes, the vulnerability of people who sell sexual services seems to look special, not in continuation of the needs other people have.

The broad array of problems for which women who sell sex seek assistance show the challenges involved in targeting services. And the current organisation of welfare for women who sell sex means that they, as migrants, are not offered single service provision at this point. When specialised services were established, one had in mind very particular groups of sex sellers, and this is no longer, and was perhaps never, the only group with a need for services. The fact that women who sell sex are targeted as a special group means that they find open doors that would otherwise be shut. But at the same time, not all women can have doors open for them, and there are costs involved in being targeted as special, as it builds on the historical and current definition of them being dangerous for us. It is thus not clear whose vulnerability is most protected by the current system, particularly as access to services does not necessarily depend on who has the greatest need.

\section{Acknowledgments}

We wish to thank the anonymous reviewers and the editors for their insightful comments that helped us greatly enhance the finished article.

\section{Conflict of Interests}

The authors declare no conflict of interests.

\section{References}

Andrijasevic, R. (2010). Migration, agency and citizenship in sex trafficking. New York, NY: Palgrave Macmillan.

Barker, V. (2018). Nordic nationalism and penal order: Walling the welfare state. London: Routledge.

Blanchette, T. G., \& da Silva, A. P. (2014). Bad girls and vulnerable women: An anthropological analysis of narratives regarding prostitution and human trafficking in Brazil. In C. R. Showden \& S. Majic (Eds.), Negotiating sex work: Unintended consequences of policy and activism (pp. 121-144). Minneapolis, MN: University of Minnesota Press.

Boccagni, P. (2017). Addressing transnational needs through migration? An inquiry into the reach and consequences of migrants' social protection across borders. Global Social Policy, 17(2), 168-187.

Brown, K. (2015). Vulnerability and young people: Care and social control in policy and practice. Bristol: Policy Press.

Brown, K., \& Sanders, T. (2017). Pragmatic, progressive, problematic: Addressing vulnerability through a local street Sex work partnership initiative. Social Policy \& Society, 16(3), 429-441.

Brunila, K., \& Rossi, L.-M. (2017). Identity politics, the ethos of vulnerability, and education. Educational Philosophy and Theory. Advance online publication. https://doi.org/10.1080/00131857.2017.1343115

Brunovskis, A. (2012). Balancing protection and prosecution in anti-trafficking policies: A comparative analysis of reflection periods and related temporary residence permits for victims of trafficking in the Nordic Countries, Belgium and Italy. Copenhagen: Nordic Council of Ministers.

Brunovskis, A. (2013). Erfaringer i fem prostitusjonstiltak gjennom et halvt år [The experiences of five social service organisations from six months of offering services to persons who sell sex]. Oslo: Fafo.

Brunovskis, A. (2016). Special rights within universal welfare: Assistance to trafficking victims in Norway. Journal of Comparative Social Work, 11(1), 1-33.

Brunovskis, A., \& Skilbrei, M.-L. (2016). Two birds with one stone? Implications of conditional assistance in victim protection and prosecution of traffickers. AntiTrafficking Review, 2016(6), 13-30. https://doi.org/ 10.14197/atr.20121662 
Brunovskis, A., \& Surtees, R. (2013). Coming home: Challenges in family reintegration for trafficked women. Qualitative Social Work, 12(4), 454-472.

Brunovskis, A., Tveit, M., \& Skilbrei, M.-L. (2010). Pusterom eller ny start? Evaluering av refleksjonsperioden for ofre for menneskehandel [A time to breathe or a new start? An evaluation of the reflection period for victims of trafficking]. Oslo: Fafo.

Brunovskis, A., \& Tyldum, G. (2004). Crossing borders: An empirical study of transnational prostitution and trafficking in human beings. Oslo: Fafo.

Demleiter, N. V. (2001) The law at the crossroads: The construction of migrant women trafficked into prostitution. In K. David \& R. Koslowski (Eds.), Global human smuggling: Comparative perspectives (pp. 257-293). Baltimore, MD: The Johns Hopkins University.

de Pérez, J. L. (2016). A criminological reading of the concept of vulnerability: A case study of Brazilian trafficking victims. Social \& Legal Studies, 25(1), 23-42.

Fineman, M. A. (2008). The vulnerable subject: Anchoring equality in the human condition. Yale Journal of Law \& Feminism, 20(1), 1-23.

Fineman, M. A. (2017). Introduction. In M. A. Fineman, U. Andersson, \& T. Mattsson (Eds.), Privatization, vulnerability; and social responsibility: A Comparative perspective (pp. 1-6). London: Routledge.

FitzGerald, S. (2010). Biopolitics and the regulation of vulnerability: The case of the female trafficked migrant. International Journal of Law in Context, 6(3), 277-294.

Florin, O. (2012). A particular kind of violence: Swedish social policy puzzles of a multipurpose criminal law. Sexuality Research and Social Policy, 9(3), 269-278.

Hatland, A. (2013). Velferdspolitikk og innvandring [Welfare policies and immigration]. In A. Hatland, S. Kuhnle, \& T. I. Romøren (Eds.), Den norske velferdsstaten [The Norwegian welfare state] (4th ed.; pp. 251-270). Oslo: Gyldendal.

Jahnsen, S., \& Skilbrei, M.-L. (2018). Leaving no stone unturned: The borders and orders of transnational prostitution. British Journal of Criminology, 58(2), 255-272.

Jahnsen, S., \& Wagenaar, H. (Eds.). (2017). Assessing prostitution policies in Europe. London: Routledge.

Kempadoo, K. (2005). From moral panic to global justice: Changing perspectives on trafficking. In K. Kempadoo, J. Sanghera, \& B. Pattaniak (Eds.), Trafficking and prostitution reconsidered: New perspectives on migration, sex work, and human rights (pp. 3-24). Boulder, CO: Paradigm Publishers.

Kock, I. E. (2017). Vulnerable persons from Bulgaria and Romania who sell sexual services in Oslo. Experiences from Pro Sentret and other actors in Oslo. Oslo: ProSentret.

Koken, J. A. (2010). The meaning of the 'whore': How feminist theories on prostitution shape research on female sex worker. In M. H. Ditmore, A. Levy \& A.
Willman (Eds.), Sex work matters. Exploring money, power and intimacy in the sex industry (pp. 28-64). London: Zed Books

Lee, M. (2007). Introduction: Understanding human trafficking. In M. Lee (Ed.), Human trafficking (pp. 1-25). Cullompton: Willan Publishing.

Loga, J. (2018). Sivilsamfunnets roller i velferdsstatens omstilling [The roles of civil society in the transformation of the welfare state]. Norsk sosiologisk tidsskrift, 2(1), 58-73.

Mingot, E. S., \& Mazzucato, V. (2018). Providing social protection to mobile populations: Symbiotic relationships between migrants and welfare institutions. Journal of Ethnic and Migration Studies. Advance online publication. https://doi.org/10.1080/ 136913X.2018.149900

Paylor, I. (2018). A short reply to the 'epistemology of harm reduction'. British Journal of Social Work, 48(2), 525-530.

Plambech, S. (2014). Between 'victims' and 'criminals': Rescue, deportation, and everyday violence among Nigerian migrants. Social Politics, 21(3), 382-402.

Sex og Samfunn. (n.d.). Kjøpt sex? Helsetilbud til personer som kjøper sex: Smittesjekk, samtale og chat [Have you bought sex? Health services to people who buy sex: Health checks, conversations and web chat]. Sex og Samfunn. Retrieved from www.sexogsamfunn. no/klinikk-og-tilbud/kjopt-sex

Showden, C. R., \& Majic, S. (Eds.). (2014). Negotiating sex work: Unintended consequences of policy and activism. Minneapolis, MN: University of Minneapolis Press.

Shubin, S. (2010). 'Where can a gypsy stop?' Rethinking mobility in Scotland. Antipode, 43(2), 494-524.

Siegel, D. (2015). Ethnicity, crime and sex work: A triple taboo. In D. Siegel \& R. de Wildt (Eds.), Ethical concerns in research on human trafficking (pp. 71-84). Cham: Springer.

Singh, S. (2017). Criminalizing vulnerability: Protecting 'vulnerable' children and punishing 'wicked' mothers. Social \& Legal Studies, 26(4), 511-533.

Skilbrei, M.-L. (2007). Natashas to liv: Østeuropeiske kvinner forteller om migrasjon, prostitusjon og skam [The double life of Natasha: Eastern-European women talk about migration, prostitution and shame]. Tidsskrift for kjønnsforskning, 31(1), 5-20.

Skilbrei, M.-L., \& Holmström, C. (2013). Prostitution policy in the Nordic region. Ambiguous sympathies. Farnham: Ashgate

Skilbrei, M.-L. (2017). Speaking the truth about prostitution. In. M. Spanger \& M.-L. Skilbrei (Eds.), Prostitution research in context: Methodology, representation and power (pp. 33-46). Abingdon: Routledge.

Smith, P. S., \& Ugelvik, T. (2017). Introduction: Punishment, welfare and prison history in Scandinavia. In P. S. Smith \& T. Ugelvik (Eds.), Scandinavian penal history, culture and prison practice: Embraced by the welfare state? (pp. 3-31). London: Palgrave 
Macmillan.

Stumpf, J. (2006). The crimmigration crisis: Immigrants, crime, and sovereign power. American University Law Review, 56(2), 367-419.

Tveit, M., \& Skilbrei, M.-L. (2008). Mangfoldig marked. Prostitusjonens omfang, innhold og organisering [A multifaceted market. The size, content and organisation of the prostitution market]. Oslo: Fafo.

Wagenaar, H. (2017). Introduction. In S. Jahnsen \& H.
Wagenaar (Eds.), Assessing prostitution policies in Europe (pp. 1-28). London: Routledge.

Ward, E., \& Wylie, G. (Eds.). (2017). Feminism, prostitution and the state: The politics of neo-abolitionism. Abingdon: Routledge.

Weitzer, R. (2012). Legalizing prostitution: From illicit vice to lawful business. New York, NY: New York University Press.

\section{About the Authors}

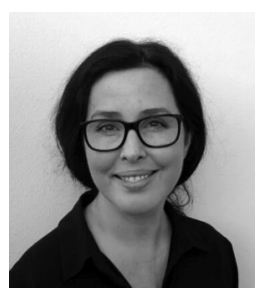

Anette Brunovskis is a Sociologist and Researcher at Fafo, an independent research institute in Oslo, Norway. She has conducted numerous studies on prostitution and human trafficking, with a particular focus on assistance provision and anti-trafficking responses in Norway, Eastern Europe, and the Balkans. She has also published several articles and chapters on research methodology and ethics in the study of vulnerable and hard-to-reach populations.

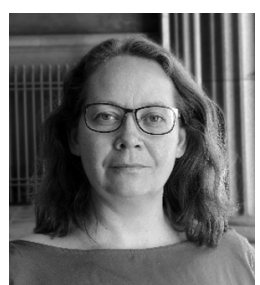

May-Len Skilbrei is a Professor of Criminology at the University of Oslo, Norway. Skilbrei has researched prostitution and prostitution policies since the mid-1990s. In 2013, she published a book with Ashgate on Nordic prostitution policy together with Charlotta Holmström. In the last ten years, she has been involved in research on human trafficking, migration and gender, and has published articles in Crime \& Justice, Women \& Criminal Justice, Sexuality Research \& Social Policy, Ethnos and British Journal of Criminology. 